Chałdaś-Majdańska Justyna, Bieniak Monika, Karska Katarzyna. Interpersonal communication between nurses and hospitalized patients - a review of Polish literature. Journal of Education, Health and Sport. 2020;10(2):97-106. eISSN 2391-8306. DOI http://dx.doi.org/10.12775/JEHS.2020.10.02.013

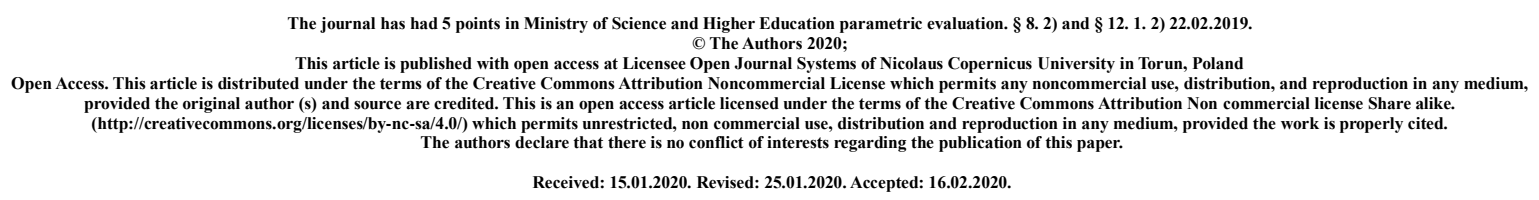

\title{
Interpersonal communication between nurses and hospitalized patients - a review of Polish literature
}

\author{
Justyna Chałdaś-Majdańska ${ }^{1,3}$, Monika Bieniak ${ }^{1,3}$, PhD Katarzyna Karska ${ }^{2,4}$ \\ ${ }^{1}$ Department of Nursing Development, Faculty of Health Sciences, Medical University \\ in Lublin \\ ${ }^{2}$ Department of Foreign Languages, Medical University of Lublin \\ ${ }^{3}$ Students' Scientific Association for Medical Communication at Department of Foreign Languages, Medical \\ University of Lublin \\ ${ }^{4}$ The supervisor of Students' Scientific Association for Medical Communication at Department of Foreign \\ Languages, Medical University of Lublin
}

\section{Summary}

Each negative change in the health condition causes a great discomfort to patients. It is a difficult situation and therefore it generates both anxiety, stress, and other negative emotions. Therefore, communication plays an important role in relieving the anxiety and stress and may reduce negative emotions and feelings. Communication is a situation in which a proper exchange of information and contact between the nurse and the patient is established thus helping the patient feel secure and understood. The communicate information belongs to the professional responsibilities of a nurse and it is an important element of the patient care.

The aim of the study was to analyze the results of research presented in Polish scientific literature on the subject of communication between a nurse and a hospitalized patient. A selection of scientific articles from the years 2010-2019 were reviewed. A multi-stage process of data selection was employed and both the analysis inclusion criteria and a critical review 
were used. After having searched the Internet databases, 5 papers were identified which met the analysis inclusion criteria. The main research method employed was the diagnostic survey method.

The analysis of the published research results allowed for the identification of the following categories related to interpersonal communication between the patient and the nurse:

- $\quad$ quality of communication between the nurse and the patient from the patient's perspective;

- nurses' knowledge about the importance of communication in the professional environment and its components in relations with patients;

- $\quad$ interpersonal communication style employed between the nurse and the patient.

Interpersonal communication, both verbal and non-verbal, is an important element of nursing care. Interestingly, both nurses and patients notice the need to improve their communication skills. The results obtained indicate the need for further research in the field of interpersonal communication in the nurse-patient relationship. Consequently, it has been observed that a systematic education through trainings and workshops on proper communication with a hospitalized patient is required. .

Key words: interpersonal communication; patient; nurse.

\section{Introduction}

The correct communication between the therapeutic team and the patient is a prerequisite for a successful treatment. Currently, an increase in public awareness is observed and therefore it reflects the growing need of patients to obtain more information about their health, causes of the disease, therapy and prognosis. A correct and effective interpersonal communication allows each patient to feel in the focus of clinical procedures thus to be the co-decision maker. Such approach is particularly significant in the case of hospital procedures that are unclear and unknown to the patients. That is why, the sense of security and trust that can be created by medical personnel is of great importance to the patients. [14]

Nursing is a difficult profession requiring both high professional competence, and also the knowledge of the correct rules of interpersonal communication. It is impossible to treat a patient without prior establishing good contact. Communication establishing occurs through information exchange expressed in words, gestures, facial expressions, appearance, tone of voice and many other non-verbal signals. The uncontrolled and unaware application of those non verbal signals can impair the establishment of good patient - nurse rapport. [9]

The development of medical knowledge has caused an increased demand for qualified medical staff, including nursing staff. That is why, interpersonal competences in nursing include the ability to communicate with people, and the ability to select and apply effectively those methods and means of communication with the patient and their family. The appropriate selection of communication methods facilitates decision making in difficult situations, such as threat to the patients' health and the actual illness.

The above-mentioned competences includes verbal communication and alternative communication methods. The appropriate selection of the right means of communication allows the nurse to establish good therapeutic contact with the patient and to recognize 
anxiety in the patient. It also allows the patients express their opinion so that the most effective intervention can be made. [2]

Nurses should be trained to communicate effectively in the professional area as well as in the scientific and research context. The nurse should be able to communicate with patients in different advancement of a disease. The above statements had a significant impact on the introduction of interpersonal communication training into the general nursing training programmes. [2]

\section{The aim of the work}

The aim of the study was to analyze the research results available in Polish scientific literature on the subject of communication between nurses and hospitalized patients.

\section{Material and method}

The Google Scholar search engine was used to review the scientific literature from the years 2010-2019. It was followed by a manual search in scientific journals: 21st Century Nursing, Polish Nursing, Nursing Problems.

A multi-stage process of selection of the identified works was used so that the appropriate analysis inclusion criteria could be applied. Next, the selected workes were critically evaluated.

The analysis inclusion criteria were as follows:

- $\quad$ originality of papers;

- $\quad$ publication from the years 2010-2019;

- $\quad$ language of publication: Polish;

- $\quad$ compliance with the following keywords: interpersonal communication, patient, nurse;

- communication as the main research problem discussed in the publication.

An important assumption for search of the papers was the occurrence of the following words: communication, nurse and patient in the title of the article.

The exclusion criteria were similar, that is all articles dealing with either communication or medical personnel were excluded. An article dealing with the majority of the issues in focus in the context of nursing personnel and not other medical personnel was included into the review. This is why, the present review of the literature mostly discussed the following two research problems:

1/ How often are studies on interpersonal communication between the patient and the nurse conducted?

2/ What results were obtained from research dealing with the interpersonal communication between the nurse and the hospitalized patient?

\section{Results}

All the answers for the posted research questions were obtained. In the result of the internet databases search, four papers were identified which met the analysis inclusion criteria. The analysis of published research results allowed to identify the following categories of problems relating to the interpersonal communication between nurses and hospitalized patients: 
- the quality of communication between the nurse and the patient from the patient's perspective;

- nurses' knowledge about the importance of communication in the profession and its components in relations with patients;

- interpersonal communication style used in the relationship between the nurse and the patient.

Table 1. The analysis of the analyzed scientific articles.

\begin{tabular}{|c|c|c|c|c|c|}
\hline No & Title of the article & Authors & $\mathbf{P Y}^{1}$ & Methodology & Study group \\
\hline 1. & $\begin{array}{l}\text { Interpersonal } \\
\text { communication style } \\
\text { used in the relation } \\
\text { between the nurse } \\
\text { and the hospitalized } \\
\text { senior patient. }\end{array}$ & $\begin{array}{l}\text { M.Lato- } \\
\text { Pawłowska, } \\
\text { J.Hoffman- } \\
\text { Aulich }\end{array}$ & 2019 & $\begin{array}{l}\text { Method: observation of } \\
\text { relationship and communication } \\
\text { styles used by nurses during their } \\
\text { daily activities. } \\
\text { Research tool: data card with the } \\
\text { following: ward, patient's age, } \\
\text { gender, category of care, nursing } \\
\text { activity, used communication, } \\
\text { patient's response. }\end{array}$ & $\begin{array}{l}20 \text { patients aged over } 60 \text { in } \\
\text { various categories of care needs, } \\
\text { patients of hospital wards } \\
\text { (internal medicine, neurology, } \\
\text { cardiology, surgery) in the } \\
\text { Lubuskie region }\end{array}$ \\
\hline 2. & $\begin{array}{l}\text { Communication of } \\
\text { the nurse and the } \\
\text { patient within } \\
\text { hospital environment. }\end{array}$ & $\begin{array}{l}\text { A.Włodarcz } \\
\text { yk, } \\
\text { A.Goździals } \\
\text { ka }\end{array}$ & 2015 & $\begin{array}{l}\text { Method: Diagnostic survey. } \\
\text { Research tool: author } \\
\text { questionnaire. }\end{array}$ & $\begin{array}{l}100 \text { female and male nurses } \\
\text { during their masters training at } \\
\text { the Andrzej Frycz Modrzewski } \\
\text { Cracow University }\end{array}$ \\
\hline 3. & $\begin{array}{l}\text { Clinical } \\
\text { communication } \\
\text { problems with } \\
\text { hospitalize patient }\end{array}$ & $\begin{array}{l}\text { J.Surmacka, } \\
\text { M.Motyka }\end{array}$ & 2015 & $\begin{array}{l}\text { Method: documentation analysis } \\
\text { Research tool: information from } \\
50 \text { letters sent to a popular } \\
\text { magazine sent in respond for the } \\
\text { request to share the experiences of } \\
\text { hospital stay. }\end{array}$ & $\begin{array}{l}50 \text { readers of a popular } \\
\text { magazine describing their } \\
\text { experiences as patients. }\end{array}$ \\
\hline 4. & $\begin{array}{l}\text { Nurses knowledge } \\
\text { concerning the } \\
\text { significance of } \\
\text { interpersonal } \\
\text { communication in the } \\
\text { nursing career - a } \\
\text { multicenter study. }\end{array}$ & $\begin{array}{l}\text { I.Radecka, } \\
\text { I.Łopacińska } \\
\text { Z.Kopański, } \\
\text { I.Brukwicka, } \\
\text { J.Rowiński }\end{array}$ & 2014 & $\begin{array}{l}\text { Method: diagnostic survey. } \\
\text { Research tool: author } \\
\text { questionnaire. }\end{array}$ & $\begin{array}{l}144 \text { nurses aged from } 24 \text { to } 57 \\
\text { from randomly selected health } \\
\text { care facilities i Cracow, Warsaw } \\
\text { and Jarosław }\end{array}$ \\
\hline
\end{tabular}

The quality of communication between the nurse and the patient from the patient's perspective The problems occurring in the area of communication between patients and the nursing team have been identified as the main obstacles on the way to satisfy the basic psychosocial needs of patients. Patients most frequently $(68 \%, \mathrm{~N}=50)$ complained about the lack of information concerning their medical condition, the care and procedures performed and a general reluctance to provide the above information. According to the respondents' opinion $(50 \%, \mathrm{~N}=$ 50), they were treated instrumentally and did not experience sufficient mental support and care. It was manifested in the way the medical tasks were being performed on them, rather than with them. The above problems belong to the category of no need for security.

The following problems belong to the category of lack of providing security needs, acceptance and respect and the patients reported:

\footnotetext{
${ }^{1}$ PY - Publication Year
} 
- $\quad$ ignorance to their fears and concerns reported by them $(36 \%, \mathrm{~N}=50)$;

- $\quad$ manifestation of disapproval in contacts and disregard $(28 \%, \mathrm{~N}=50)$;

- $\quad$ lack of respect for intimacy during care and caring procedures $(28 \%, \mathrm{~N}=50)$;

- $\quad$ ignorance of reported pain $(12 \%, \mathrm{~N}=50)$

- $\quad$ lack of gentleness during nursing activities $(10 \%, \mathrm{~N}=50)$.

- limited contact $(32 \%, \mathrm{~N}=50)$ with the nursing team leading to lack of satisfaction of the need for safety and acceptance.

It was noted that patients $(17 \%, \mathrm{~N}=50)$ reported the lack of qualifications on the part of the nursing personnel to communicate bad news. Additionally, patients and were left alone after receiving the bad news. This situation proved to have a significant correlation with the lack of security and respect for the patients. What is more, patients' $(12 \%, \mathrm{~N}=50)$ biological needs for rest and sleep were frequently violated through noise and lights during night hours. Subsequently, their needs for safety in sleep were not satisfied. Some patients observed (10\%, $\mathrm{N}=50$ ) that they could not rest or sleep safely due to the noisy way the nursing duties were being performed. [15]

\section{Nurses' knowledge concerning the role of communication in the professional environment and communication components in contact with patients}

Nurses are aware of the role communication has in the contact with hospitalized patients, their attitudes and behaviour. The study group described their level of theoretical and practical knowledge on interpersonal communication as good. Nevertheless, the conducted research indicated that very few of the survey participants knew the rules and techniques of effective interpersonal communication. Most respondents $(85 \%, \mathrm{~N}=144)$ indicate that care for establishing interpersonal communication is an important element of their work and has an impact on its effectiveness. The surveyed nurses appreciate the role of interpersonal communication, yet they stressed that the courses on communication they attended rarely met their expectations. The respondents agree, that the difficulties in communication between nurses and hospitalized patient are the consequence of the work overload that the nurses experience. The majority of respondents agree that despite being assertive they demonstrate empathy in their professional environment. Detailed data in presented in Table 2 below. [10.16] 
Table 2. Nurses' knowledge concerning the role of communication in the professional environment and communication components in contact with patients - distribution of answers.[10.16]

\begin{tabular}{|c|c|}
\hline Questions & Answers \\
\hline $\begin{array}{l}\text { Participation in trainings dealing } \\
\text { with interpersonal communication }\end{array}$ & $\begin{array}{l}64 \%(\mathrm{~N}=144) \text { of the respondents attended trainings and } \\
\text { courses dealing with interpersonal communication }\end{array}$ \\
\hline $\begin{array}{l}\text { The need for additional trainings } \\
\text { dealing with interpersonal } \\
\text { communication }\end{array}$ & $\begin{array}{l}10 \%(\mathrm{~N}=144) \text { of the respondents declared the need for } \\
\text { additional trainings dealing with interpersonal } \\
\text { communication and } 90 \%(\mathrm{~N}=144) \text { did not declare the need } \\
\text { for such training. }\end{array}$ \\
\hline $\begin{array}{l}\text { The role of communication skills } \\
\text { in the effectiveness of duties. }\end{array}$ & $\begin{array}{l}85 \%(\mathrm{~N}=144) \text { of the respondents acknowledged the role of } \\
\text { communication skills in the effectiveness of duties. }\end{array}$ \\
\hline $\begin{array}{l}\text { Emotions accompanying nurses in } \\
\text { their contacts with co-workers at } \\
\text { the same level of professional } \\
\text { career. }\end{array}$ & $\begin{array}{l}11 \%(\mathrm{~N}=144) \text { of the respondents admitted that they had } \\
\text { negative feelings towards their co-workers, } 58 \%(\mathrm{~N}=144) \\
\text { declared neutral emotions and only } 31 \% \quad(\mathrm{~N}=144) \\
\text { experienced very positive emotions towards their co-workers. }\end{array}$ \\
\hline $\begin{array}{l}\text { Nurses; emotions present when } \\
\text { contacting patients }\end{array}$ & $\begin{array}{l}12 \%(\mathrm{~N}=144) \text { of the respondents admitted to form their } \\
\text { relation with the patients basing on negative emotions, } 42 \% \\
(\mathrm{~N}=144) \text { on neutral emotions and } 46 \%(\mathrm{~N}=144) \text { on very } \\
\text { positive emotions. }\end{array}$ \\
\hline $\begin{array}{l}\text { Satisfaction based on the doctor- } \\
\text { nurse contact }\end{array}$ & $\begin{array}{l}14 \%(\mathrm{~N}=144) \text { of the respondents claimed that doctor-nurse } \\
\text { contact did not comply with their expectations, } 65 \%(\mathrm{~N}=144) \\
\text { claimed that these relations were average, and only } 21 \% \\
(\mathrm{~N}=144) \text { declared that they were very good. }\end{array}$ \\
\hline $\begin{array}{l}\text { The frequency of the occurrence of } \\
\text { conflicts in the nursing } \\
\text { environment }\end{array}$ & $\begin{array}{l}8 \%(\mathrm{~N}=144) \text { of the respondents referred to such incidents as } \\
\text { frequent, 64\% }(\mathrm{N}=144) \text { regarded them as occasional, and } \\
28 \%(\mathrm{~N}=144) \text { asserted they are very rare. }\end{array}$ \\
\hline $\begin{array}{l}\text { The influence of the atmosphere at } \\
\text { work in the establishing of } \\
\text { interpersonal communication at } \\
\text { work }\end{array}$ & $\begin{array}{l}19 \%(\mathrm{~N}=144) \text { of the respondents practically did not perceive } \\
\text { the atmosphere at work as a factor influencing the } \\
\text { establishment of interpersonal contacts at work, } 52 \% \\
(\mathrm{~N}=144) \text { declared that the atmosphere at work had a great } \\
\text { role in the establishing of interpersonal communication }\end{array}$ \\
\hline $\begin{array}{l}\text { Nursing work satisfaction level and } \\
\text { professional burnout }\end{array}$ & $\begin{array}{l}43 \%(\mathrm{~N}=144) \text { of the respondents claimed that their work } \\
\text { created opportunities for personal development, yet as many } \\
\text { as } 43 \% \text { respondents }(\mathrm{N}=144) \text { noted that they were threatened } \\
\text { with professional burnout or they were already experiencing } \\
\text { professional burnout, } 14 \% \quad(\mathrm{~N}=144) \text { had no opinion } \\
\text { concerning professional burnout. }\end{array}$ \\
\hline $\begin{array}{l}\text { Level of professional dedication to } \\
\text { the nursing job }\end{array}$ & $\begin{array}{l}72 \%(\mathrm{~N}=144) \text { of the respondents felt dedicated to their job, } \\
\text { yet } 28 \%(\mathrm{~N}=144) \text { felt the contrary. }\end{array}$ \\
\hline $\begin{array}{l}\text { Communication knowledge and } \\
\text { skills acquired when at a nursing } \\
\text { school }\end{array}$ & $\begin{array}{l}34 \%(\mathrm{~N}=100) \text { of the respondents agreed that graduating from } \\
\text { a nursing school allowed them to acquire the basic } \\
\text { communication knowledge and skills necessary in } \\
\text { interpersonal contacts with the hospitalized patients, and } 42 \% \\
(\mathrm{~N}=100) \text { disagreed with the above, } 5 \%(\mathrm{~N}=100) \text { had no } \\
\text { memory of it. }\end{array}$ \\
\hline Level of theoretical knowledge on & $45 \%(\mathrm{~N}=100)$ of the respondents claimed that the level of \\
\hline
\end{tabular}




\begin{tabular}{|c|c|}
\hline interpersonal communication & $\begin{array}{l}\text { theoretical knowledge on interpersonal communication was } \\
\text { good, } 28 \%(\mathrm{~N}=100) \text { average, } 13 \%(\mathrm{~N}=100) \text { very good, } 11 \% \\
(\mathrm{~N}=100) \text { insufficient, a } 3 \%(\mathrm{~N}=100) \text { admitted to have no } \\
\text { knowledge on interpersonal communication. }\end{array}$ \\
\hline $\begin{array}{l}\text { Level of the practical skills in } \\
\text { interpersonal communication }\end{array}$ & $\begin{array}{l}53 \%(\mathrm{~N}=100) \text { of the respondents assessed the level of the } \\
\text { practical skills in interpersonal communication as good, } 23 \% \\
(\mathrm{~N}=100) \text { average, } 15 \%(\mathrm{~N}=100) \text { very good, } 8 \%(\mathrm{~N}=100) \\
\text { insufficient, and a } 1 \%(\mathrm{~N}=100) \text { admitted to have no practical } \\
\text { skills in interpersonal communication. }\end{array}$ \\
\hline $\begin{array}{l}\text { Attendance in trainings and } \\
\text { courses dealing with interpersonal } \\
\text { communication }\end{array}$ & $\begin{array}{l}55 \%(\mathrm{~N}=100) \text { of the respondents did not attend trainings and } \\
\text { courses dealing with interpersonal communication, } 10 \% \\
(\mathrm{~N}=100) \text { have no memory of such trainings, } 15 \%(\mathrm{~N}=100) \\
\text { were willing to attend trainings and courses dealing with } \\
\text { interpersonal communication if it is required by the } \\
\text { employer, } 9 \%(\mathrm{~N}=100) \text { had interest in such training, and } 4 \% \\
(\mathrm{~N}=100) \text { declared that such training was unnecessary. }\end{array}$ \\
\hline $\begin{array}{l}\text { Sources of ineffective interpersonal } \\
\text { communication with a hospitalized } \\
\text { patient }\end{array}$ & $\begin{array}{l}85 \%(\mathrm{~N}=100) \text { of the respondents enumerated overload with } \\
\text { nursing duties as the most frequent source of ineffectiveness } \\
\text { in interpersonal communication, } 67 \%(\mathrm{~N}=100) \text { claimed that it } \\
\text { was the patients' negative attitude toward medical personnel } \\
\text { that impacted the communication, } 58 \%(\mathrm{~N}=100) \text { claimed that } \\
\text { it was due to too high expectations on the part of the patients } \\
\text { and their families, } 44 \%(\mathrm{~N}=100) \text { claimed that it was due the } \\
\text { patients' lack of involvement and initiative, } 40 \%(\mathrm{~N}=100) \\
\text { admitted to a low level of communication skills, and } 22 \% \\
(\mathrm{~N}=100) \text { observed lack of dedication on the part of the } \\
\text { nursing personnel. }\end{array}$ \\
\hline $\begin{array}{l}\text { Psychological support during a } \\
\text { conversation with a difficult patient }\end{array}$ & $\begin{array}{l}\text { As many as } 52 \%(\mathrm{~N}=100) \text { of the respondents indicated no } \\
\text { psychological support during conversations with difficult } \\
\text { patients } 42 \% \quad(\mathrm{~N}=100) \text { claimed that such support was } \\
\text { available, and } 6 \%(\mathrm{~N}=100) \text { did not know if such support was } \\
\text { available. }\end{array}$ \\
\hline
\end{tabular}

\section{The style of interpersonal communication used in the relationship between the nurse and the patient}

It is most frequent that nurses when communicating with hospitalized patients aged 60 and more use a partnership style when the patients are classified as first- or second- degree. The non-partner egocentric style in nursing activities manifested by infantilization, imperatives, disrespect, and intimidation, was used in relation with highly-dependent patients classified as third-degree. The use of the non-partner allocentric style was not observed during the performance of treatment-related activities and nursing duties. The author research was supplemented with the observations on patients' reactions to the communication styles used by nurses when performing treatment-related activities and nursing duties. Samples of such observations are provided in Table No. 3 below. [7] 
Table 3. Samples of observations on patients' reactions to the communication styles used by nurses when performing treatment-related activities and nursing duties.

\begin{tabular}{|c|c|c|}
\hline No. & $\begin{array}{c}\text { Communication } \\
\text { style }\end{array}$ & Sample of the observation \\
\hline 1. & Partner style & $\begin{array}{l}\text { Internal medicine ward. Female second-degree patient aged } 65 \text {. Nursing activity: } \\
\text { intravenous infusion. Words used by the nurse: Mrs. Anna, I came to give you an } \\
\text { antibiotic. Please tell me if you feel any disturbing symptoms, e.g. pain or any } \\
\text { pressure from inside. First, I will check if the catheter is not obstructed. The } \\
\text { patient's reaction verbal and / or non-verbal: Patient remained calm, smiling, } \\
\text { accepting the performed action, thanked for the treatment. }\end{array}$ \\
\hline 2. & $\begin{array}{l}\text { Non-partner } \\
\text { style with } \\
\text { imperative }\end{array}$ & $\begin{array}{l}\text { Internal medicine ward. Male second-degree patient aged } 79 \text {. Nursing activity: } \\
\text { blood pressure measurement. Words used by the nurse: Lift your sleeve up, or } \\
\text { otherwise how should I check it?! (The patient rushes to lift to sleeve, and after the } \\
\text { pressure is taken he asked about the readings - } 145 / 85 \text {. The patient asked if this was } \\
\text { a good reading. The nurse responded: can be! The patient's verbal and non-verbal } \\
\text { reaction: the patient was embarrassed and asked no more questions. }\end{array}$ \\
\hline 3. & $\begin{array}{l}\text { Non-partner } \\
\text { style with } \\
\text { infantilization }\end{array}$ & $\begin{array}{l}\text { Internal medicine ward. Female third-degree patient aged } 75 \text {. Nursing activity: } \\
\text { taking blood sample for testing. Words used by the nurse: Madame please give me } \\
\text { your little hand because I came to take some of your little blood for testing. Oh, } \\
\text { what a poor little hand, so many stabs. Never mind, we will try somehow. Squeeze } \\
\text { your little fist. I will tap just a little the spot, maybe this little vein of yours will be } \\
\text { more visible. Now hold here, so you will not get a little bruise (the words: hand, } \\
\text { blood, fist, vein, bruise in Polish were used in diminutive forms). The patient's } \\
\text { verbal and non-verbal reaction: The patient was patient during the procedure, a } \\
\text { slight grimace of pain when the needle was inserted, she said nothing during the } \\
\text { procedure and thanked afterwards. }\end{array}$ \\
\hline 4. & $\begin{array}{l}\text { Non-partner } \\
\text { style with } \\
\text { disrespect }\end{array}$ & $\begin{array}{l}\text { Internal medicine ward. Male third-degree patient aged } 68 \text {. Nursing activity: } \\
\text { intravenous infusion. Words used by the nurse: (The nurse said nothing, she looked } \\
\text { for the catheter and applied the medication). The patient's verbal and non-verbal } \\
\text { reaction: no reaction. }\end{array}$ \\
\hline 5. & $\begin{array}{l}\text { Non-partner } \\
\text { style with } \\
\text { intimidation }\end{array}$ & $\begin{array}{l}\text { Internal medicine ward. Male third-degree patient aged } 84 \text {. Nursing activity: } \\
\text { change of bed position. Words used by the nurse: Sir, we move you up a while ago } \\
\text { and now you are down again. You don't weigh five kilos so that we could move up } \\
\text { every moment. Don't resist and let go of the handles! Sir, my spine is going to } \\
\text { break, what are you doing? No you need to manage at least for two hours in this } \\
\text { position. The patient's verbal and non-verbal reaction: The patient was sad, } \\
\text { suffering and he said nothing. }\end{array}$ \\
\hline
\end{tabular}

\section{Discussion}

The analysis of Polish literature indicates a small number of studies on interpersonal communication between the nurse and a hospitalized patient $[7,10,15,16]$. Polish researchers, dealing with the subject of communication, refer mainly to the issues of communication between widely understood medical personnel and the patient; a doctor and the patient and communication taking place between different members of medical personnel $[4,6,8,9,11,12,17,18]$.

Foreign literature deals with the issues of interpersonal communication between the nurse and the patient more frequently and the authors also included research concerning the nurses' participation in training courses. Benerjee et al. in their own research present a 1-day Comskil training programme for nurses, consisting of an introductory lecture followed by three 2-hour 
sessions. Each session includes a 30-minute scientific presentation and a 90-minute roleplaying session with simulated patients. The above training programme dealt with four areas of communication skills: 1/ empathy in communication with the patient; 2 / discussing nursing goals; 3/ discussing death and dying; 4/ communication with the patient in difficult family situation. [1]

It has been observed that foreign researchers conducted qualitative research more frequently. Shafipour et al. interviewed nurses and patients about job dissatisfaction; routine care and distrust concerning the nurses' competences. The research indicated that the are a number of factors negatively influencing the communication between a patient and a nurse such as: workload; working under pressure; difficult nursing tasks; shortage of highly qualified nurses and interference of patient relatives in the nursing duties. [13] However, surveys conducted by Kargar Jahromi et al. indicated that communication barriers from the patient's point of view include: heavy workload of nurses; age, gender and language barriers between the nurse and the patient and the strict moral code represented by the nurses. [5]

The studies initiated by Chan et al. identified two major topics concerning nurse-patient communication. These included: the workload of nurses and the working environment as well as the relation between the nurse and the patient and expectations shaped by these roles. [3]

Regardless of the kind of research conducted there is one issue which remains unaltered both in Polish and foreign observations on the broadly understood interpersonal communication between medical personnel and the nurse and the hospitalized patient in particular. All authors agreed on the need for further research in this area. $[1,3,4,5,6,7,8,9,10,11,12,13,15,16,17,18]$.

\section{Conclusions}

1. Interpersonal, verbal and non-verbal communication is an important element of nursing care.

2. Both nurses and patients notice the need to improve mutual communication skills.

3. The obtained results indicated the need for further research in the field of interpersonal communication in the nurse-patient relationship.

4. It seems necessary to conduct systematic education in the form of trainings and courses in the field of proper communication with a hospitalized patient.

\section{References}

1. Banerjee SC, Manna R, Coyle N, Penn S, Gallegos TE, Zaider T, Krueger CA, Bialer PA, Bylund CL, Parker PA. The implementation and evaluation of a communication skills training program for oncology nurses. Translational Behavioral Medicine. 2017; 7(3): 615623. doi: 10.1007/s13142-017-0473-5. PMID: 28211000; PMCID: PMC5645276.

2. Bielawska J. Kompetencje zawodowe pielęgniarki. Zeszyty Naukowe Państwowej Wyższej Szkoły Zawodowej im. Witelona w Legnicy. 2012; nr 8, s. 5-17. ISSN 1896-8333.

3. Chan EA, Wong F, Cheung MY, Lam W. Postrzeganie przez pacjentów ich doświadczeń $\mathrm{z}$ komunikacją pielęgniarka-pacjent $\mathrm{W}$ warunkach onkologicznych: skoncentrowane badanie etnograficzne. Public Library of Sciences One. 2018; 13 (6): e0199183. doi:10.1371/journal.pone.0199183. PMID:29912967; PMCID:PMC6005521. 
4. Jarosz M.J., Kawczyńska-Butrym Z., Włoszczak-Szubzda A. Modele komunikacyjne relacji lekarz- pacjent- rodzina. Medycyna Ogólna i Nauki o Zdrowiu. 2012; tom 18, nr 3, s. 212-218.

5. Kargar Jahromi M, Ramezanli S. Ocena barier przyczyniających się do wykazania skutecznej komunikacji pielęgniarka-pacjent w szpitalach edukacyjnych w Jahrom, 2014. Global Journal of Health Sciences. 2014;6 (6), s. 54-60. doi: 10.5539 / gjhs.v6n6p54. PMID: 25363103; PMCID: PMC4825499.

6. Kaźmierczak A. Wpływ komunikacji z personelem medycznym na doświadczanie choroby przez pacjentów. Homo Communicativus. 2011; 1 (6): 133-140.

7. Lato-Pawłowska M. S., Hoffmann-Aulichb J. B. Styl komunikacji interpersonalnej stosowany $\mathrm{W}$ relacji między pielęgniarką a hospitalizowanym pacjentem $\mathrm{w}$ wieku senioralnym. Pielęgniarstwo Polskie. 2019; tom 73,s.277-284.DOI: https://doi.org/10.20883/pielpol.2019.37.

8. Meller D., Milik A. Komunikacja interpersonalna w zakładach opieki zdrowotnej. Zarządzanie i Finanse. Journal of Management and Finance. 2014; tom 12, nr 2, s. 133-144.

9. Radecka I., Łopacińska I, Kopański Z., Brukwicka I., Lischynskyy Y., Rowiński J. Znaczenie komunikacji interpersonalnej w pielęgniarstwie. Journal of Clinical Healthcare. 2014; nr 4, s. 6-9.

10. Radecka I., Łopacińska I., Kopański Z., Brukwicka I, Rowiński J. Wiedza pielęgniarek na temat znaczenia komunikacji interpersonalnej $\mathrm{w}$ zawodzie- badania wieloośrodkowe. Journal of Clinical Healthcare. 2014; 4,s. 19-22.

11. Rębiałkowska-Stankiewicz M. Komunikacja lekarza z pacjentem w chorobie nowotworowej. Psychiatria. Tom 3, nr 4, s. 238-244.

12. Rudnicka-Drożak E., Nowicki G., Naylor K., Rzońca P., Młynarska M., Farenglom A. Ocena jakości komunikacji personel medyczny- pacjent na przykładzie Szpitalnego Oddziału Ratunkowego (SOR). Ostry Dyżur. 2014; tom 7, nr 3, s. 73-78.

13. Shafipour V, Mohammad E, Ahmadi F. Barriers to nurse-patient communication in cardiac surgery wards: a qualitative study. Global Journal of Health Science. 2014;6(6):23444. doi: 10.5539/gjhs.v6n6p234. PMID: 25363126; PMCID: PMC4825530.

14. Sułkowska J., Kuźmicz I., Malinowska-Lipień I., Lickiewicz J., Makara-Studzińska M., Brzostek T. Znaczenie zastosowania porozumienia bez przemocy oraz coachingu w komunikacji z pacjentem. Sztuka Leczenia. 2017; nr 2, s. 43-53.

15. Surmacka J., Motyka M. Problemy w komunikacji klinicznej $\mathrm{z}$ pacjentem hospitalizowanym. Problemy Pielęgniarstwa. 2015; tom 23, nr 3, s. 386-391.

16. Włodarczyk A., Goździalska A. Komunikowanie się pielęgniarki z pacjentem w warunkach szpitalnych. W: Troska o zdrowie w aspekcie społecznym. Część 2- pod red. Goździalska A., Jaśkiewicz J. Oficyna Wydawnicza AFM, Kraków 2015; s. 27-41. ISBN 978-83-65208-25-5

17. Włoszczak-Szubzda A., Jarosz M. J. Pacjent- choroba- medyk. Znaczenie i role w komunikacji. Medycyna Ogólna i Nauki o Zdrowiu. 2011; tom 17, nr 2, s. 105-110.

18. Włoszczak-Szubzda A., Jarosz M. J. Rola i znaczenie komunikacji w relacji- pacjentrodzina. Medycyna Ogólna i Nauki o Zdrowiu. 2012; tom 18, nr 3, s. 206-211. 